\title{
Baltic Connections
}

Archival Guide to the Maritime Relations

of the Countries around the Baltic Sea

(including the Netherlands)

1450-1800

Volume I

Denmark, Estonia, Finland, Germany

\author{
Edited by \\ Lennart Bes, Edda Frankot \\ and Hanno Brand
}

BRILL

LEIDEN . BOSTON

2007 


\title{
BALTIC CONNECTIONS
}

\section{Changing Patterns in Seaborne Trade, c. 1450-1800}

\author{
by HANNO BRAND (Hanse Research Centre, Groningen University)
}

\section{Introduction}

Each year during the late Middle Ages and the Early Modern period, many hundreds of ships plied the narrow waters of the Sound in both directions, carrying the produce of the economies located on the shores of the Baltic and the North Sea. The Baltic seaborne trade was based on the exchange of raw materials, foodstuffs and minerals from the east, and on the influx of the rich commodities and domestic industrial produce from the west. It gave rise to a trading system that was structured on the basis of the pivotal role staple markets played in the purchase and distribution of the commodities that were transported along the vast waterway stretching from the Finnish Gulf to the Danish Kattegat. The struggle for control over these markets, their hinterlands and the seaborne trading routes that linked them is the common element in the history of the maritime powers east and west of the Sound and the changing patterns of trade in the region. This narrative attempts to trace the main lines of these developments from various angles over a period of almost 400 years. Starting with the rise and fall of the German Hanse, the dynamics of the Baltic system are be elaborated by analysing the advance of the Dutch in the Baltic and the emergence of new powers in the eastern Baltic. Finally, the application of mercantilist policies in the region and the outcomes of the Great Nordic Wars explain the changing relations between the seaborne nations in and beyond the Baltic.

\section{The Hanseatic Era}

In the late Middle Ages, maritime trade in the Baltic developed under the aegis of the German Hanse. The origins of this League lie in the loose associations of long-distance merchants, notably from northern Germany and Westphalia, who succeeded in securing trading privileges abroad to the benefit of all subjects of the Holy Roman Empire. It was, however, Lübeck and the Wend towns along the northern German coasts that built the core of the urban League as it started to take shape in the final decades of the twelfth century. During its heydays (c. 13701474), the League comprised 200 towns, which cooperated in a rather loose fashion and covered an area stretching from Reval (Tallinn) in the east to Kampen on the Zuiderzee coast in the west.

The successful linkage of sea, river and land routes is one of the reasons for the prolonged existence of the Hanseatic trading system. Northern Europe's main rivers and roads served the vast Prussian and Russian hinterlands and connected Germany's urban markets and production centres to the Baltic ports. Lübeck served in many ways as the starting point of this system. Already in the 1160 s, its merchant families started to settle in the Wend nuclei 
along the Pomeranian coast (Wismar, Stralsund, Rostock, Stettin (Szczecin) and Greifswald). Northern Germans were also involved in the founding or refounding of cities like Riga, Danzig (Gdansk) and Reval. From there they opened up the Prussian and Russian hinterlands, bringing the southern Baltic ports within the orbit of the western markets. These cities comprised the core of the Hanseatic trading system in the Baltic, whilst Hamburg and Bremen were the main ports on the North Sea. On the western flank of the Hanseatic region, Cologne emerged as the Hanse's main trading partner with England and with it the satellites (Kampen, Deventer) along the Zuiderzee coasts came into being.

The trading network of the Hanse merchants was based on a system of staple markets and foreign offices (Kontoren), in Bruges, London, Bergen (Norway) and Novgorod (Russia). Since all foreign Hanseatic trade was supposed to be concentrated in these Kontors and the adjacent staple markets, they represented an indispensable instrument in the League's efforts to dominate the few trading routes that connected the eastern Baltic to the west. Because of its strategic position on the Trave River, Lübeck maneged to direct all major trading flows in the Baltic and from the North Sea to its port and staple market. In this way, the town controlled all trans-shipments at the Elbe, Stecknitz and Trave estuaries.

Merchants from Lübeck and the Wend towns made their fortune by exchanging the western rich trades (e.g. high-quality cloth, spices and wines) for the minerals and the agrarian and sylvan products of the north and the east. Among these were bulk commodities such as Prussian and Livonian hard dusk grains, hemp and flax, as well as unprocessed timber, deal boards, masts and klapholz, which was used for barrel making. Farmers exploiting the vast Livonian, Russian and Scandinavian forests produced tar, pitch destined for the shipbuilding industries and potash for glass making. Bar iron and copper were produced in the mines in Sweden and south of Krakow. The Finnish and Russian hinterlands were the main providers of such high-value products as wax, furs, leather and skins. On top of this, the League was engaged in the Baltic herring and beer trade, and Lübeck had a monopoly on the exports of Lüneburg salt.

Lübeck's position as the largest entrepôt in the Baltic system was reflected in its leading position in the Kontors. There, members of its rich merchant families maintained contact with their trading partners abroad, fostered intense diplomatic contacts with foreign powers and carefully guarded the trading interests of the Hanse merchants and the abundant privileges that had clipped the wings of potential competitors. The Hanse Kontors and the merchant settlements around these acted as entrepôts for the commodities over which the Hanse had established a quasi monopoly. These were furs and wax from Novgorod, dried cod from Bergen, wool and cloth from London and Boston (on England's west coast), and highquality cloth from Flanders, Brabant and Holland, which was exported through the staple market of Bruges.

Underlying this long-distance network, a range of trading routes developed between the staple markets on the northern and southern Baltic coasts. Most Hanseatic cities were engaged in triangle trade between their home markets, Lübeck, and Sweden, Finland or Novgorod. Stockholm - Sweden's main port for iron and copper - had a substantial number of Hanseatic merchants among its inhabitants. Åbo (Turku) and Viborg were the important staple markets for Finnish timber and tar, whilst Narva and Novgorod were the main gateways to the Russian hinterland. Shipping on the Livonian coasts was concentrated at Reval, Riga, Dorpat (Tartu) and Pernau (Pärnu), the main suppliers of grain, hemp, flax and naval stores. Already in the fourteenth century, attempts to protect the trade with the Livonian and Russian hinterlands led to prolonged rivalry with merchants from Lübeck and the Wend towns, who tried to evade the local markets in order to cut transaction costs. The ports of Danzig, Königsberg (Kaliningrad) and Elbing (Elblag) were the main outlets for Prussian grain and timber, which lay at the root of their trade on the Swedish and Finnish coasts. 
However, what challenged Lübeck's dominion was not the increasing density of Baltic triangle shipping, but primarily the developing Sound trade. The Baltic, Prussian and Wend towns - which engaged in much the same trade and thus shared the same markets - were in fact potential rivals rather than loyal allies. Rising commercial centres like Reval, Riga and particularly Danzig were therefore exploring new markets in order to escape Lübeck's tutelage. Growing demand for Prussian and Livonain grain at the western markets and the availability of cheap French bay salt, which rapidly replaced the Lüneburg salt exports, were the main factors behind the expansion of the eastward Sound trade at the expense of Lübeck. By the end of the fourteenth century, eastern Baltic cogs and hulks were plying the waters along the North Sea and Atlantic coasts, supplying the ports of Amsterdam and Zeeland with increasing amounts of grain, as well as loading salt on the French coast at Brouage or cloth in Holland or England. Keenly circumventing the staples of Lübeck and Bruges, the eastern Baltic merchants gradually eroded the traditional Hanseatic trading system, which was based on the almost complete control of the few sea routes linking the Kontors abroad. Especially Danzig, which controlled as much as 75 per cent of the total Baltic grain exports, developed into a major rival of Lübeck, as its merchants sailed directly to the transit ports of London, Amsterdam and Antwerp's satellites along Zeeland's waters.

On the western flank of the Hanse region, Lübeck's supremacy was challenged not only by Cologne, but also by the Zuiderzee towns of Kampen, Deventer and Zwolle. These three towns had rather ambiguous relations with the core of the League, varying from earnest sentiments of loyalty to downright defiance. Loyalty was the result of their enjoying the Hanseatic privileges abroad, which offered advantageous trading positions in the eastern Baltic, English and Norse markets. Defiance was related to Lübeck's discriminating policies against the merchants from the County of Holland and notably Amsterdam. The latter's prolonged struggle for free access to the Sound posed a serious threat to the League's dominion in both Scandinavia and the eastern Baltic. Exposed on the League's westernmost frontiers, and therefore relying heavily on the transit traffic between Holland and the Hanseatic towns, the Zuiderzee towns fundamentally opposed measures that put their trading relations with the County at risk. On top of this were Lübeck's efforts to maintain the staple at Bruges, which suffered under the flowering of direct trading relations between Dutch, English and Hanseatic merchants from all the major towns on the League's western flank.

Hamstrung by the failures of their own system, Lübeck and the Wend towns offered little coordinated resistance against the free-riding activities of their rivals along the Baltic and Zuiderzee coasts. On several occasions, the Prussian, Livonian and Zuiderzee towns brushed aside Hanseatic policies that impaired excellent trading relations with the northern Low Countries. During the Holland-Wend war of 1438-1441, with free Dutch access to the Baltic at stake, Prussia refused to join the Hanseatic grain blockade against the County of Holland. The Zuiderzee towns preferred neutrality in order not to put their trade with Holland at risk. In 1470, the Wend towns tried to exclude Holland's shipping from the Sound traffic in an attempt to revive discriminating regulations at both the Bruges and the Trave staple. Highly valued commodities from the east had to be shipped through Lübeck and Hamburg, whilst Dutch high-quality cloth destined for the Baltic had to be exported through the harbour of Bruges, where Wend ships were awaiting. With the Hanseatic towns on both the eastern and the western flank refusing to cooperate, the operation was a failure. Danzig and the other Baltic towns were prepared to ally with Lübeck and the Wends in the wars with Denmark in the early sixteenth century, but they pulled back as soon as the League's belligerent attitude seriously jeopardised trading relations with Holland. This process of fragmentation contributed in two ways to the prolonged demise of the German Hanse: it resulted in the increasing isolation of Lübeck and the Wend towns within the League, and it encouraged the development of a dense network of trading routes between the harbours along the shores of 
the Baltic, the North Sea and the western Atlantic, which finally led to the demise of the traditional staple system.

Views that maintain that these episodes were a turning point in the decline of the Hanseatic seaborne trade through the Sound are corroborated by a long-term analysis of the Sound Toll registers. The levying of the Sound dues, which were introduced in 1429 by the Danish king in order to tap some of the revenues of the increasing east-west trade, gave birth to an impressive registration system of all ships that passed through the Sound between 1497 and 1857. Despite interpretation difficulties concerning the origins of the ships and their cargoes, the registers represent the historian's most important tool for reconstructing both the volume and the value of Baltic shipping over the centuries. In the sixteenth century, the Hanseatic east-west trade gained importance, since while there were fewer than 1000 vessels passing through the Sound each year between 1500 and 1540, in the 1560s some 3280 vessels and in the years around 1590 some 5038 vessels passed through it annually. It is estimated that about 80 per cent of this flow was headed towards the Hanseatic towns situated on the northern German and the eastern Baltic coast. This was reflected in the size of the Hanseatic fleet. At the end of the sixteenth century, it had about 1000 ships with a total carrying capacity of 45,000 lasts (90,000 tons). Compared to the situation 100 years earlier, this was an increase of 50 per cent. Though lagging far behind the Dutch, the League's fleet capacity outstripped that of England and France.

Lübeck succeeded in maintaining its position in the Baltic until well into the seventeenth century. Shipbuilding in Lübeck blossomed in the decades around 1600: each year until about 1640, fifteen to twenty ships left the slipways of the yards on the Trave River. Still, Lübeck's role and that of the other Hanseatic towns became much more confined to the Baltic itself as, with the rise of the Atlantic system, trading routes moved to the west to the benefit of Antwerp, Amsterdam and London. From 1600 on, Hanseatic seaborne trade was mostly limited to short hauls between the Scandinavian and the southern Baltic ports, with only sporadic long-distance voyages to the Mediterranean or across the oceans. This led to the remarkable situation that one of Europe's largest fleets was cut off from Europe's newly emerging maritime flows. Only Hamburg escaped this fate, by ceasing its resistance to the English merchant adventurers and allowing a massive influx of Protestant immigrants from Antwerp and of converted Portuguese Jews, who had escaped the claws of the Inquisition. Thanks to the immigrants' world-encompassing networks, the Elbe harbour rapidly replaced Lübeck as the largest maritime centre on the Baltic shores. The transfer of former Hanseatic business into foreign and, progressively, Dutch hands marked the final stage of the prolonged demise of the League. The final blow came in 1648, when Sweden occupied the Pomerian and northern German shores. With the Wend cities of Stettin, Stralsund and Wismar becoming Swedish, and Hamburg, Bremen and Lübeck forced into benevolent neutrality, the days of the League were numbered. In 1669, the last general Hanseatic meeting assembled in Lübeck in order to confirm the League's status as a quasi impotent power in the Baltic.

\section{The Rise of New Sea Powers}

In the first decades of the sixteenth century, Lübeck and its Wend allies clearly recognised that Holland's skippers and merchants posed a major threat to their dominium in the Baltic. Within 150 years, Holland's and Zeeland's seafaring towns had changed from loyal partners offering naval support in the League's war against Denmark of 1368-1370, into dogged competitors that effectively undermined the traditional Hanseatic monopolies. This shift caused the division of the northern Low Countries into two economic regions, with the towns east of the Zuiderzee integrated into the Hanseatic League, and the County of Holland, with 
Amsterdam as its emerging zenith, into the territories of the Burgundian and Habsburg princes.

Growing distance from the Hanse was the inevitable result of Holland's increasing engagement in the intertwined salt and grain trade along the east-west axis through the Sound. Already engaged as the carriers for mostly Hanseatic merchants in the fourteenth century, skippers and merchants from sucg towns as Veere, Zierikzee and Middelburg in Zeeland, and from Amsterdam and the "Water Cities" (i.e. Hoorn, Enkhuizen, Edam, Monnikendam and Medemblik) situated north of it, set sail to the many make-shift harbours along the northern German, Livonian and Prussian coasts. Instead of calling at the Hanseatic staple markets, they purchased wheat and rye directly from the local large-scale producers in order to reduce prices to the lowest possible level. With the population growing and the traditional markets in the Somme region disappearing, the grain trade was the prime mover behind Holland's breakthrough in the Baltic. It is estimated that the loading capacity of the merchant fleet grew from 19,000 lasts around 1500 to 80,000 lasts in 1567. In the same period, imports of Baltic grain increased from 10,000 lasts to about 60,000 lasts. In the last quarter of the fifteenth century, grain imports attained a regular pattern with exports from Danzig, Riga and Reval increasing.

Transports of Baltic grain and French bay salt interlocked about 1440 and led to the emergence of Holland's profitable triangle trade between the eastern Baltic, the Zuiderzee and Zeelandic ports, and the French Atlantic coast. In its wake, exports to the Baltic of Dutch herring, high-quality cloth and French wines developed, whilst Holland's booming shipbuilding industry was the main consumer of the traditional Baltic raw materials like timber, hemp, flax and tar. The competitive effect of low transaction costs, already realised through the elimination of Hanseatic middlemen and investments in the direct Baltic-Atlantic trade, were maximized as a result of large cuts in shipbuilding costs and innovations in ship design. The increased speed of new, full-rigged Dutch ships, combined with adaptations that facilitated the carrying of bulky goods, allowed smaller crews, giving the ships a considerable advantage over the heavy, well-manned Hanseatic vessels. Also a high degree of rationalisation of both trade and transport provided Holland with an advantage over the Hanseatic League.

By 1530, Holland's reliance on the Baltic trade and on imports of Prussian and Livonian grain had become so great that the Habsburg political leaders realised that any interruption of the Sound trade would bring the County to the verge of famine and social disruption as a result of widespread unemployment in the booming maritime sector and exporting industries. Such a dependence was already visible in the second half of the fifteenth century, and it had obliged the Burgundian and Habsburg princes — be it initially with reluctance — to offer their formidable state support against the League's attempts to bring Holland's Sound trade to a standstill. They intervened in favour of the abolition of the League's staple policies and activated their diplomatic apparatus in order to secure Holland's free access to the Baltic against Lübeck's blockading policies. It was due to the intervention of Charles V that Holland was exempted from the Sound tolls in 1544, which constituted a major step towards Holland's domination of the Baltic trading system for the next two centuries.

Free access to the Baltic markets, combined with low transactions costs and a still increasing share of the combined salt and grain trade, paved the way for the establishment of Amsterdam as a major repository linking the Baltic to the western and southern European markets. Dutch factors settled in many Baltic ports to organise their business. They did their best to circumvent the local middlemen, who were eating into their profits, and advanced credits in order to stimulate trade and local shipbuilding to the benefit of their enterprises. Especially Danzig shipwrights profited from the inflow of Dutch orders. The Dutch omnipresence on the Scandinavian, Livonian and Prussian markets in the sixteenth 
century reflects the state of disintegration of the traditional Hanseatic system, which slowly gave way to the current principles of free trade, shared by the Dutch and the rising sovereign powers in the Baltic. Persistent views, however, that the Dutch were already the undisputed masters of the Baltic around 1500, are no longer tenable. A comparison of the passages of Hanseatic and Dutch ships on the basis of the Sound Toll registers reveals that the two powers remained competitors, with the volume of their shipping through the Sound still rather balanced around the middle of the sixteenth century.

The dominance of Lübeck and its Wend allies further crumbled as the Danish kings gradually succeeded in loosening the Hanseatic grip on their domestic markets. Sweden, Denmark and Norway - which had been brought under one crown by the Kalmar Union of 1397 - had virtually been degraded to a natural hinterland of the Hanse. Since the early fifteenth century, the Danish kings had occasionally favoured Dutch and English trading at the expense of Wend dominance. Tension with Lübeck rose in 1429 when the Sound Toll was imposed. Denmark's strategic position on the Sound posed a clear threat to Hanseatic traffic and provoked an open sea war. The conflict ended in the military humiliation of the Danes and the exemption of the Wend towns from the Sound levies. This reduced the Danish king's role to that of a mediator during the Holland-Wend War of 1438-1441, and attempts to encourage Dutch trade on the Baltic in the following decades were foiled by the overwhelming power of the northern German towns.

The succession to the throne of Christian II (1514-1523), who was allied through marriage with the Habsburg emperor and sovereign in the Low Countries, brought about a dramatic shift in relations with the League. War between Denmark and Lübeck had broken out already in 1509-1512 as a result of the anti-Hanseatic policies of King Hans (1481-1513). But Christian II's visions of the establishment of a Northern Trading Company that was to control the entire Sound trade, combined with a liberal trading policy favouring the Dutch, provoked unprecedented resentment within the Hanse's leading circles. Carefully exploiting opposition in Denmark against Christian's domestic policies and a Swedish uprising under Gustav Wasa, the combined Wend forces chased the Danish king into exile. Two new kings - Frederick I (1524-1533) in Denmark and Gustav I Wasa (1523-1560) in Sweden — gained their thrones thanks to Lübeck's interventions. Hopes that the League's supremacy was now firmly re-established vanished as both kings immediately decided to allow all foreign powers free access to the Baltic markets.

Anti-Dutch feelings flared up again during the stormy but conservative regime of the Lübeck Protestant burgomaster Jurgen Wullenwever in the early 1530s. A blockade of the Sound entirely directed against the Low Countries and attempts to revive the traditional Hanseatic staple system aroused deep suspicions even among Lübeck's closest allies. Danzig and the Livonian towns refused to provide military support and Hamburg secretly came to terms with the Dutch in 1534. With the League's cohesion now fully eroded, Lübeck and the Wend towns grudgingly accepted the conditions of the Peace of Speyer in 1544, which concluded a two-year war between Habsburg and Denmark and stipulated free access for the Dutch to the Sound and the Baltic markets.

The containment of the League's influence in the Baltic proceeded as Gustav I Wasa and his successors in now independent Sweden adopted an aggressive policy in order to secure the supply lines from the east. Notably, the Swedish historian Attman spent almost his entire career showing that Sweden's eastward expansion served complete control over the eastern Baltic trading routes and staple harbours in Livonia (Riga, Reval, Narva) and eastern Finland (Viborg). In its struggle for the Baltic markets, Sweden provoked prolonged rivalry not only with Lübeck, but also — and primarily — with Russia and Poland, which had emerged as new seaborne powers on the Baltic coasts. The kingdom of Poland emerged from the ruins of the Teutonic Order, which after the military defeat at the battle of Tannenberg in 1411 had 
lost much of its political and economic impact in the region. The incorporation of the east Prussian territories into Poland in 1466 liberated the Hanseatic towns of Danzig and Elbing from competition with the Teutonic Order. The formation of a Polish corridor along the Baltic coast implied the elimination of the Order's control over the communication lines into the extended Lithuanian and Prussian hinterlands on which the Baltic grain trade largely depended. Supported by the Polish suzerain, Danzig's trade towards the west rapidly gained importance. Rye exports accounted for 10,000 lasts in the 1490s and quintupled in the course of the sixteenth century. Although Elbing's economic development was much more modest, the town benefited from the declining influence of the Hanse and the benevolence of the Polish crown, as evidenced in 1585 by the establishment of the English Eastland Company within its walls.

Further north, the emergence of the Muscovite empire of Grand Duke Ivan III (1462-1505) represented another threat to the German Hanse. The closure of the Hanse Kontor in Novgorod by the Russian prince in 1494 was much more of a symbolic nadir than an outright catastrophe for the League's trading interests. Hanseatic trade with Russia itself was now directed towards Reval and Riga, which benefited greatly from the shift as, besides the Germans, also Dutch and English merchants increasingly focused their activities on these towns. Tension built up among the League's members, however, as a consequence of increasing protectionism in the eastern Baltic towns. In order to strengthen their grip on direct trade with Russia, they imposed measures that were intended to prevent all foreign traders, including merchants from Lübeck and the Wend towns, from circumventing the staples of Riga and Reval. However, such policies only widened the already existing fissures within the League, as they emphasised the Baltic towns' desire to escape Lübeck's tutelage. Pressure from outside increased as the Russians reached the Baltic coasts in 1558, occupying Livonia and the Hanseactic towns of Dorpat and Narva. With the former destroyed and the latter developed into a Russian alternative for the harbours of Riga and Reval, three independent new states had made significant inroads into the Hanseatic supremacy in the eastern Baltic waters.

Since Poland, Russia and Sweden shared the same goal - namely control over the communication routes between the Baltic shores and the Russian hinterlands - the economic climate in the region was determined by the outcomes of military conflicts. The Swedish King Eric XIV (1560-1568) attempted to thwart direct trade with Narva and proceeded to establish staples for Russian trade in both Viborg and Reval. The Swedish occupation of Reval in 1561 and the following blockade of the Narva staple provoked the First Nordic War (1563-1569), in which Lübeck, Denmark and Poland combined their forces to combat Swedish aggression. Though a peace treaty was signed shortly after Lübeck's bombardment of Reval in 1569, the main issues remained unresolved. With Reval firmly in Swedish hands and the struggle over the Narva staple continuing, this was the beginning of a long period of wars between Russia and Sweden. The conflicts led to the seizure of Narva by Sweden's King John III (1568-1592) in 1581 and, fourteen years later, the Russian approval of the establishment of staples at Viborg and Reval. As in 1621 Riga also fell into the hands of King Gustav II Adolph, the Russians were sealed off from the Baltic, leaving the remains of the Hanseatic trade in the region to the mercy of the Swedish kingdom.

\section{The Second Dutch Advance in the Baltic}

Despite the impressive number of ships passing through the Sound in the sixteenth century, both the volume and the value of the Dutch Baltic trade remained modest. The majority of the ships had a capacity of less than 50 lasts, and since merchandise for the Baltic countries was available only in small quantities in the Dutch entrepôt, vessels often sailed eastward on 
ballast. The range of products transported to the east consisted mainly of salt, herring, cloth and wines. In the 1580s, it was the English and the Hanseatics who were involved in the exchange of the wide range of commodities that were in demand in Poland, Lithuania and Ukraine. There, the land-owning nobility were experiencing a steep increase in prosperity, which provoked a growing demand for jewellery, spices, manufactures and other highly valued commodities. The transport of high-quality textiles was very much in the hands of the English merchant adventurers and the German Hanse. Hamburg and Lübeck still controlled the seaborne trade to Danzig, Königsberg, Riga, Reval, Viborg and Stockholm, and were the main re-importing centres of colonial products like spices and sugar. The shipping of valuable merchandise from Scandinavia and the eastern Baltic (e.g. yarn, leather, furs, tallow and tar) was predominantly organised by merchant houses in Lübeck, Hamburg and London, whilst Sweden's major export products (bar iron and copper) reached the west almost exclusively via the Lübeck staple market. Lübeck merchants also had by far the largest share of the trade with Sweden, Finland and Russia and still crowded the markets of Reval, Riga, Danzig, Narva and Novgorod. Although the German Hanse's role in the Sound trade had been considerably undermined by the Dutch and English competition, it still wielded influence in important segments of the markets across the Baltic in the decades around 1600.

The Sound Toll registers show that a second Dutch advance in the Baltic was taking place in the 1590s as Dutch trade in Mediterranean and colonial wares started to eclipse that of Hamburg and Lübeck. This was the result of the more diversified triangle trade between the Baltic, the western Atlantic coasts and the Mediterranean. Danzig grain was shipped by Dutch merchants directly to Lisbon and Venice, where they sourced the Mediterranean produce demanded in the Baltic. Spain, Portugal and France were also markets for naval stores as well as Swedish copper and iron; they were also the north's main providers of salt, woollens and wines. The Baltic, however, remained primarily the source of the Dutch domestic market and the Republic's main supplier of grain, timber and naval stores. The availability of these basic commodities - especially of grain - gradually transformed the Amsterdam market into the focal point of European trade. Re-exports of grain were already a feature of Amsterdam's expansion around 1550, but they gained importance in the 1590s as famine ravaged southern Europe.

In the words of the American historian Jan de Vries, it was such extensions of Dutch trade into other parts of Europe that led in the seventeenth century to Amsterdam's rise as Europe's new entrepôt. For a while, its position was unparalleled as the Dutch gained primacy in colonial trade with the East and West Indies, in Atlantic fishing and whaling, and in Russian trade via Archangel. In the seventeenth and eighteenth centuries, Dutch exports - and in particular the influx of such colonial wares as sugar, tea, coffee and tobacco - to the Baltic rose dramatically. Dutch ships carried 14.5 million pounds of colonial wares through the Sound in the years 1661-1670. Fifty years later, the volume had more than doubled. Being the Low Countries' main supplier of basic commodities and the main market for its domestic and colonial produce, their political leaders could only acknowledge the key position of the seaborne mercantile traffic through the Sound, calling it "the mother of all trades".

The development of the fluitschip is a major reason for the Low Countries' supremacy in the Baltic after 1600. The fluit was constructed around 1595 in order to maximise carrying capacity and slash construction and equipment costs. Its design, characterised by an almost flat bottom and a long hull, revolutionised the transport of bulk commodities through the shallow Baltic coastal waters. Contrary to the then current preference for converting naval ships for merchants use, the fluit was uniquely designed for mercantile purposes. As a result, construction costs were cut by replacing traditional oak with fir and pine, which made the ship much lighter and easier to handle. A Dutch fluit could be crewed by half as many men as a traditional vessel, whilst construction costs were reduced by almost 50 per cent. The 
introduction of the fluit had an enormous impact on shipbuilding practices, as in the subsequent centuries its design served as an example for ship builders in all major yards across the Baltic. Dutch knowledge of shipbuilding was exported throughout the Baltic, giving a new impulse to the yards of Altona, Copenhagen, Stockholm, Danzig, Riga and St. Petersburg, where immigrants from the Low Countries took leading positions.

\section{Mercantilism in the West Baltic}

As the Baltic ports were virtually clogged with Dutch (and English) ships, governments redesigned their policies in order to reduce foreign influence on both their seaborne trade and their 'national' economies. The mercantile policies of the Danish King Christian IV (15961648) combined with his pursuit of political hegemony in the western Baltic, posed a serious threat to the Dutch advance. Tensions rose after Denmark's victory over Sweden during the Kalmar wars of 1611-1613, which resulted in a ban on all Dutch traffic to Sweden and a sudden increase of the Sound Toll duties. In order to secure free entrance to the Baltic, the Dutch entered anti-Danish alliances with the Hanseatic league in 1613 and with Sweden in 1614. These alliances forced Christian IV to pull back, while the Dutch also imposed some sort of Pax Neerlandica on the Baltic waters, obliging the surrounding powers to guarantee free and secure shipping in the region. Danish mercantilism challenged the Low Countries again in the 1630s. A Spanish-Danish commercial treaty of 1632 was designed to undermine Dutch-Iberian trade to the Baltic. The treaty indeed triggered an increase in DanishMediterranean trade and a revival of the construction of large ships in the Norse harbours. Trade to the Baltic was severely hit by another increase in the Sound dues, which primarily affected the Dutch since the new levies specifically concerned commodities like grain, flax, hemp and herring. In addition, a new toll at Glückstadt was imposed, creaming off the burgeoning Elbe traffic. As negotiations with Denmark had no effect, the Dutch navy entered the Sound in 1645, escorting a huge number of merchant vessels. Under the threat of an attack against Copenhagen, Christian IV annulled the new levies at the Sound and in Glückstadt. The agreement of 1649 reinforced the Dutch trading position in the Baltic even more, since it discriminated against Hanseatic and Swedish shipping through the Sound.

The shift of Sweden's war efforts to Prussia and Germany during the Thirty Years War seriously undermined King Christian's ambitions in his struggle for Baltic dominion. The acquisition of Gustav II Adolph (1611-1632) in 1632 of the northern German shores, along the Baltic and the North Sea, was followed by successful Swedish campaigns in 1643 and 1657 in Jutland. On both occasions Denmark had to give up territories in the Baltic and several provinces along the eastern coast of the Kattegat and the Sound, thus losing its supreme strategic position at the entrance to the Baltic. It marked the beginning of Sweden's Age of Greatness, which was to last until 1721, when Swedish naval forces were worsted by the galleys of the Russian Tsar, Peter the Great. Until then, however, Sweden controlled an area stretching from the Sound in the west to the Bay of Riga in the east.

On several occasions, Sweden's expansion in the Baltic provoked the intervention of the Dutch navy in an effort to protect the Republic's commercial interests in the region. In 1656, the Republic sent a fleet to Danzig to warn off the Swedes; two years later, it was dispatched to protect Copenhagen against attacks by King Charles X, who was on the verge of imposing his authority on both sides of the Sound. The defeat of the Swedish fleet in the Sound secured for the Dutch free access to the Baltic, but also alarmed the English government, which now feared that the Dutch naval power might lead to the exclusion of the English from the Baltic trade. In the end, not war but diplomacy prevailed, as in 1660 a peace treaty between Sweden and Denmark was signed after Anglo-Dutch mediation. The Swedish 
king also promised to issue regulations to prevent any effective discrimination against foreign ships by the Swedes.

Economic relations between Sweden and the northern Low Countries remained ambiguous. Swedish military enterprises in the east were a nuisance to foreigners carrying trade, since they were accompanied by blockades of the eastern Baltic and Prussian ports and trade interruptions. Sweden's internal market, however, depended very much on the investments of foreign capital and the services offered by the financial market in Amsterdam. Dutch entrepreneurs like De Geer and Trip made a fortune in the Swedish iron, copper and weapons industries and obtained pivotal positions in Sweden's export trade. In the 1640s, Sweden had become the Dutch Republic's number one trade partner in the Baltic: about 50 per cent of Sweden's imports originated from Amsterdam's staple market, whilst all copper exports and 40 per cent of all iron exports went to the Low Countries, as did 75 per cent of the Finnish tar production. The Swedish market had also become the second pillar of the Low Countries' Baltic trade.

However, this position was challenged by the Swedish mercantile stance of 1667. Contrary to the agreement that had been reached seven years earlier, heavy tolls were imposed on salt and wine shipped on foreign ships other than those sailing under the flag of the nation of origin. The measure was clearly directed against Amsterdam and the West Frisian ports, and it triggered Dutch retaliation. As war broke out between Sweden and Denmark, in 1676 the Republic sent its navy into the Baltic. In a joint campaign with Denmark, the Swedes were defeated and forced to accept a treaty in 1679 annulling the restrictive measures, and to salvage their mercantilist aims. After that, friendly relations between Sweden and the Republic prevailed and trade was restored. The improvement of the relations with the Swedes resulted in the recovery of Dutch trade through the Sound. By the 1680s, an avarage nearly 1000 Dutch ships entered the Baltic each year, accounting for almost 60 per cent of the total traffic. However, Norse-Danish and Swedish shipping was expanding, and — with some 2000 ships - heavily outnumbered the total number of Dutch ships involved in the Sound trade in the last decade of the century.

The growth of Danish-Norse shipping was the result of prolonged mercantilism in the realm. Dutch relations with Denmark-Norway withered as the latter two countries maintained their policy to reduce their dependence on the Amsterdam entrepôt, which played a pivotal role in the distribution of Norwegian timber, fish and pitch. A Danish-Dutch guerre de com merce flared up in 1683 when the government in Copenhagen issued an aggressive tariff list. The Dutch reacted by suspending Norse imports, which forced the Danish government to withdraw its discriminating policies and to accept a new commercial treaty in 1688. Although relations then improved, Dutch pressure did not bring about a complete restoration of its position in Denmark. Exports of timber to Holland declined, as did Dutch imports of salt, spices, sugar and cloth. The Danes and the Norse had acquired their own substantial merchant fleet, though it comprised mainly small vessels, which traded directly with the English and French ports and increasingly circumvented the Amsterdam entrepôt.

\section{Changing Patterns in the East}

The Baltic trade, which had suffered under the Swedish occupation of Poland and the blockade of Danzig in the late 1620s, revived almost as soon as the invaders had retreated. Merchants from the Low Countries even extended their grip on sectors of the Baltic market formerly dominated by the English. From about 1600 onwards, Dutch trade in spices and high-quality cloth to Poland and Eastern Prussia increased to such an extent that it had almost replaced the English by around 1640. Especially in the cloth trade, the balance was 
almost completely inversed to the advantage of the Dutch: between 1580 and 1650, the English share in the Baltic markets declined from 91 per cent to 32 per cent, whilst the Dutch share rose from 40 per cent to 54 per cent in the same period. The 1640 s witnessed an unprecedented rise in grain exports, which led to a shortage of the boats that shuttled between the big ships and the warehouses on Amsterdam's canals.

The dominance of the Dutch bulk trade in the eastern Baltic started to wane in the subsequent decades. Divergent explanations for this have been put forward. Maria Bogucka advanced the thesis that the competitiveness of Baltic grain on the western markets stared to decline already in the seventeenth century as a result of a lack of efficiency on Polish farms. Others have pointed to the devastating results of the wars against the Cossacks (1648-1651) and the Swedes (1655-1660), or to a declining demand as a result of demographic stagnation in western Europe. Also the English Navigation Acts of 1660 and 1662 - which were designed to, amongst others things, limit English dependence on Dutch shipping from the Baltic - contributed to the demise. By 1700, the Dutch had been largely excluded from the carrying trade between the Baltic and English harbours, with ships from Sweden and Livonia taking their place. Contraction continued until 1750, when the average volume of grain shipped on Dutch vessels was only 50 per cent of the figure one hundred years earlier.

The decline of eastern Prussian exports is clearly expressed in the Sound dues. Whilst about 40 per cent of westward shipping had left from Danzig in the first decade of the seventeenth century, the figure was less than 20 per cent at the end of the century. The changing position of the main Prussian harbour was also reflected in the tendency of western European vessels to sail to the Livonian ports, where abundant quantities of flax, hemp, timber, naval stores, pitch and tar were available. Rising prices, growing foreign competition, high tariffs and the exhaustion of timber supplies in the Vistula hinterland obliged traders to look for more favourable markets further east. Accounts kept by Lübeck's customs indicate, for example, that during the last quarter of the seventeenth century, exports from Riga were almost double those from Danzig. Smaller ports — like Königsberg, Elbing, Pernau and Narva - also benefited from the changing patterns of trade. Already in the decades around 1600, Elbing had become Prussia's main seller of industrial raw materials; it established itself as a regional cloth staple and benefited from a stable demand for naval stores. Just before 1650, Königsberg's direct access to the Lithuanian hinterlands transformed the town into Prussia's main flax and hemp exporter.

Trade moved, however, mostly to Riga, which started to challenge Danzig's predominant export status in the region around 1700. Like Danzig's exports, Riga's depended heavily on grain, hemp and flax as well as on the local production of naval requisites, like masts, boards and deals. A sawmill and linseed-oil mill were set up with Dutch capital and labour, whilst Riga merchants invested in tanneries, rope-walks, foundries and shipbuilding facilities in the Cronstierna yards. Foreign capital and knowledge led to the development of shipyards, sawmills and flax and hemp refineries along the Narova River. This contributed to a new period of economic growth in Narva and a revival of Russian transit trade, which had been halted by the Swedish conquest of 1581.

Swedish protective policies were an important factor in the shaping of a new trading balance in the eastern Baltic. Efforts by the Swedish government to gain more from the commodities that were in demand on the English and Dutch markets resulted in the establishment of the monopolistic Swedish Tar Company in 1648. The enforced monopoly was very dentrimental to Finnish tar exports, which until then had made up about 50 per cent of Finland's total export volumes. Especially the staple towns of Åbo, Helsingfors (Helsinki) and Viborg suffered heavily under the Company's monopoly because the redirection of exports provoked a fall in imports of such indispensable commodities as salt. Local farmers 
and merchants tried to avoid the negative effects of the Swedish protective measures by performing illegal trade. Finns sent their ships to the Livonian ports, whilst skippers from Holland in south-west Sweden illegally transported timber from Norway to northern Germany, Denmark and the Low Countries.

Foreign commercial relations with Sweden were further strained by the publication in 1673 of the trade ordinance, which was reissued in 1687. One of the limitations concerned the activities of native figure heads to the benefit of foreign merchants in Sweden. Such regulations followed the restrictions on international free trade that had been issued during the reign of Gustav II Adolf. These were aimed at creating a small group of staple towns and excluding other ports and markets from direct foreign seaborne trade. After 1636, all ports north of Stockholm and Åbo were subjected to such discriminating regulations. Especially Stockholm benefited greatly from these protective policies, resulting in a steady growth of its mercantile fleet. At the end of the seventeenth century, it had almost 750 vessels, though most were small coastal craft. Larger ships - that is, those with a capacity of over 100 lasts - were nearly all owned by Swedish trading houses. Göteborg came second, though with only ten ships of more than 100 lasts, it lagged far behind the capital.

Sweden's protective policies also served its efforts to control Russian trade in the Baltic. Several grandiose projects aimed at concentrating Russian trade in the hands of naturalised merchants in order to buy up Russian grain surpluses and entire annual Russian leather productions in an effort to effectively cut the Dutch out of the market. Negotiations with the Russian government resulted in the treaty of Kardis (1661), which provided for free trade in Russia. This came to an end in 1667, however, when the Russian Tsar introduced high transit duties. In the end, only the Dutch proved capable of adapting to the difficult Russian trading conditions, whilst poor and economically less developed states like Sweden and Denmark lacked the necessary reserves. The Dutch, however, lost considerable ground on the Swedish and Finnish markets in the last decades of the seventeenth century as a result of Sweden's protective policies.

\section{Baltic Trade after the Great Nordic Wars}

The Great Nordic Wars (1700-1722) — in which Poland and Russia, and from 1710 also Denmark-Norway, combined their forces against Sweden - contributed to a dramatic shift in the balance of Baltic trade. During the first phase of the war, Scandinavian shipping eastward through the Sound by far outstripped that of the Dutch. When hostilities between Sweden and Denmark started in 1710, all Scandinavian shipping through the Sound in both directions was paralysed. Trade recovered only in 1722, when the war that had sealed the fate of Sweden's Age of Greatness came to an end. It has long been stated that notably the Dutch bulk carrying trade recovered strongly once the Nordic wars were over and remained strong until the very end of the eighteenth century. The Sound Toll registers indicate that the number of ships entering the Baltic did indeed increase after the 1720s and occasionally even surpassed the numbers of the favourable years of the early seventeenth century. In reality, however, the Dutch lost their predominant share in the Baltic rich trades to the Scandinavian and northern German ports, and at best consolidated their shipping volume in the years after 1750 .

Table: Average number of vessels passing eastward through the Sound each year, 1600-1800

\begin{tabular}{|l||l|l|l|l|l|}
\hline Period & Low Countries & $\begin{array}{l}\text { Scandinavia \& } \\
\text { northern Germany }\end{array}$ & British Isles & Others & Totals \\
\hline $1600-49$ & $1118(55 \%)$ & $398(19 \%)$ & $203(10 \%)$ & $319(16 \%)$ & 2038 \\
\hline $1650-99$ & $822(50 \%)$ & $388(24 \%)$ & $181(11 \%)$ & $243(15 \%)$ & 1634 \\
\hline
\end{tabular}




\begin{tabular}{|l|l|l|l|l|l|}
\hline $1700-49$ & $722(42 \%)$ & $407(23 \%)$ & $310(18 \%)$ & $301(17 \%)$ & 1741 \\
\hline $1750-99$ & $877(28 \%)$ & $931(29 \%)$ & $742(23 \%)$ & $626(20 \%)$ & 3176 \\
\hline
\end{tabular}

Source: J.A. Faber, "Structural Changes in the European Economy during the Eighteenth Century as Reflected in the Baltic Trade", in: W.G. Heeres et al (eds.), From Dunkirk to Danzig. Shipping and Trade in the North Sea and the Baltic 1350-1850 (Hilversum, 1988), p. 90.

The above table suggests a direct correlation between the contraction period of the Polish and East Prussian grain trade, which lasted until about 1740, and a decline in the number of ships entering the Baltic between 1650 and 1750. Since the Great Nordic Wars caused an interruption of the Sound trade, the slight recovery in the first half of the eighteenth century must have taken place after 1720 . The second half of the eighteenth century witnessed a steep increase in absolute numbers, to the benefit of English, Swedish, Danish-Norse and northern German shipping. There are manifold reasons for the shifting trade balance. The Dutch share in the shipping of both colonial wares and wine and salt from the Iberian peninsula and France diminished as their direct trade with the Baltic increased. Much shipping was directed to Hamburg, which in the eighteenth century became the major entrepôt for commodities like sugar, rice, coffee, tea and tobacco. Such developments contributed to the erosion of the Amsterdam staple, which was increasingly circumvented. The rise in the number of ships passing through the Sound was largely caused by an increase in the herring exports of the towns in the Göteborg area and by the expansion of coastal trade through the Sound to the benefit of the northern Frisian towns in both northern Germany and the Low Countries. Such vessels were small and carried modest quantities of salt, wine and herring to the Baltic.

The Dutch decline in the Baltic trade was thus both absolute and relative. The downward trend was mirrored in the decline of Dutch exports from the eastern Baltic. Between 1720 and 1780, the Dutch share in timber export shrunk from two-thirds to one-fifth, that in tar from more than 50 per cent to less than 25 per cent and in hemp from 44 per cent to 19 per cent. On top of this was the prolonged decline of the Baltic eastward grain trade, which recovered only after 1740. However, the Dutch share in the Baltic grain trade remained very important, ranging between 80 and 95 per cent of the total Baltic output in the first half of the century. Its share started to fall immediately after 1740 as England, France and the Mediterranean countries, as well as Hamburg, took over the role of the Amsterdam entrepôt. Nevertheless, the Dutch decline was less pronounced than that of the total Baltic grain trade.

Notably, Jonathan Israel pointed to the effects of mercantilist policies on the shifting balance in the Baltic trade. Once the Great Wars were over, a new style of mercantilism started to dominate commercial policies in Prussia, Russia, Sweden and Denmark. From 1720 onwards, governmental interventionism reached an unprecedented level. A series of protectionist measures were taken in order to curtail all foreign influence in industrial development and 'national' seaborne trade. In 1718, for example, Prussia banned the export of raw wool, which was formerly absorbed by the Dutch market. The consistency of its policies were reflected two years later in a ban on the import of foreign cloth to the benefit of the local industries. The measures had an effect in the sense that not Dutch but Prussian cloth was purchased by Russia, as governmental attempts to establish a domestic cloth industry had failed. In Denmark, a prohibition on the import of foreign woollens, silks, refined sugar and other colonial produce coincided with the royal founding of the Danish Asiatic Company. Royal custom concessions, granted to the provincial ports, stimulated entrepôt trading with Norway and opened the way to a lively Atlantic trade in the 1740s. The Danish-French commercial treaty of 1742 allowed merchant houses in Danish Altona, close to Hamburg, to gain ground in the Mediterranean. Outward-bound vessels leaving Copenhagen returned with tea from China and sugar from the Danish plantations on St. Croix. Most colonial imports were destined for re-export to Germany and the eastern Baltic regions, with refined sugar 
representing almost 50 per cent of Copenhagen's exports value in the 1760s. The Danish entry to the world market attracted foreign trading houses. For example, the Dutch De Coninck trading house established itself in Copenhagen, and the immigrant Beets, De Vliegher and Van der Smissen families headed Altona's main shipyards.

Mercantilist policies in Sweden also combined an almost complete prohibition on foreign manufacture with protective measures aimed at foreign seaborne trade. The Swedish Produktplakat of 1724 was designed to curtail foreign shipping to Sweden, as well as to undermine imports of foreign luxury products. Dutch trade in Swedish bar iron to Amsterdam indeed diminished to the benefit of direct exports on Swedish ships to England and the Mediterranean. As iron imports declined, prices rose and profits narrowed, Dutch investors residing in Sweden (e.g. the De Geer and the De Grill families), retreated from active trade and concentrated on financing. The big trading houses, both foreign and domestic, in Stockholm and Göteborg now advanced short-term credits to Swedish iron producers, which shipped their products under the Swedish flag to consuming markets around the North Sea and the Mediterranean. Foreign influence on the Finnish tar trade was reduced in 1765 when the Swedish government loosened its restrictive policies and allowed the Finnish staple harbours to trade directly on foreign markets. Commercial protectionism clearly benefited direct Swedish shipping and affected the position of foreign competitors from the west on the domestic market. Between 1740 and 1780, both Britain and the Low Countries lost much of their position in the Baltic region.

What mainly tipped the scales in the Baltic, however, was political rivalry for control over production markets. The economies of the south-coast Baltic states were competitive because of their dependence on the export of raw materials and unprocessed projects. Sweden, on the other hand, remained a major purchaser of foodstuffs and the main supplier of iron in the region, as it had been 100 years earlier. In the second half of the eighteenth century, almost all the ships involved in this traffic were Swedish. Nevertheless, the Swedish balance with the three Baltic countries was essentially negative. At its peak in the 1750s Poland for example purchased only 3 per cent of the Swedish export totals, declining to less than 1 per cent in the last decades of the century.

The outcome of the Great Northern Wars provided Russia with its first direct links with the Baltic, as Sweden's former possessions around Novgorod and the coastal regions in Estonia and Livonia, including Riga, Reval and Narva, fell into its hands. The peace treaty of Nystad (Uusikaupunki) in 1721 marked Russia's breakthrough to the Baltic. The empire increasingly advanced in the trading routes across the Baltic, and the newly-founded harbour of St. Petersburg gradually surpassed the former Baltic ports of Riga and Reval before 1800. As Russia now enjoyed unlimited access to the Livonian grain markets and was Sweden's most important trading partner, both powers for once were on the same side during the Seven Years' War (1756-1763). By 1780, Russia had fully outflanked Swedish Pomerania, which for a long time had benefited from Sweden's preferential treatment. Poland's trade succumbed under the effects of the First Partition, resulting in a diversion of Danzig's grain trade to Elbing in East Prussia and a serious, though short decline in its seaborne trade at the very end of the century. In 1792, only 65 ships left its harbor, a figure that is in stark contrast to the yearly average of 1100 ships landing in Danzig in the years before the Polish Partition.

The former Hanseatic towns of Lübeck and Hamburg on the northern German coasts suffered heavily from Swedish protectionism. Lübeck's seaborne trade in the Baltic relied on the exports of finished textiles to the north. It had been an important trading partner in the decades around 1700, but it never recovered from the effects of the Swedish mercantilist restrictions, which since the 1740 had favoured the rise of a domestic textile industry. Hamburg on the other hand concentrated on the shipping of foodstuffs and raw products. Exports of cheese, meat, grain and woollens to Sweden put Hamburg at the top of the 
northern German cities in the Baltic, as it dominated Sweden's trade in the 1780s and reinforced its position as an international staple on the Elbe estuary.

Russia's rise as a seaborne power caused a reorientation of the trade flows, which instead of the traditional and dominating south-north direction now increasingly ran along an eastwest axis with Stockholm as one of the Baltic's gravity points. This trend was reinforced by Denmark's rise as a major consumer on the Swedish markets. Between 1740 and 1780, figures indicating the volume of the cross-Sound trade almost tripled, with tar, copper and timber (and not iron) being the most important commodities. Danish North Sea herring imports, which had represented a major export commodity since the sixteenth century, seriously declined as a result of a spectacular rise in catches along Sweden's western coasts. The loss was only partially neutralised by Denmark's increasing mingling in the worldwide sugar rivalry in which, however, the big western colonial powers still took the lead. Though the roles had changed, at least from a Swedish point of view, England and the Mediterranean countries had gained ground on the Dutch Republic. In the Baltic, it was Russia and Hamburg that gained at the expense of Swedish Pomerania and Poland. In fact, it was a competitive change to both the east and the west of the Sound that led to the reshuffling of trading relations in the eighteenth-century Baltic system.

\section{Selective bibliography}

- Angerman, N., Hamburg und Rußland in der Frühen Neuzeit (Hamburg, 1972).

- Arens, I., "Seefahrts- und Handelsverbindungen zwischen Baltikum und Skandinavischen Norden in der Zeit der zweiten Hälfte des 17. Jahrhunderts", in: Journal of Baltic Studies, 11 (1980), pp. 142-149.

- Atmann, A., The Struggle for Baltic Markets. Powers in Conflict 1558-1618 (Göteborg, 1979).

- Blockmans, W., and L. Heerma van Voss, "Urban Networks and Emerging States in the North Sea and Baltic Areas. A Maritime Culture?", in: J. Rooding and L. Heerma van Voss (eds.), The North Sea and Culture (1550-1800) (Hilversum, 1996), pp.10-20.

- Bogucka, M., "Amsterdam and the Baltic in the First half of the Seventeenth Century", in: idem, Baltic Commerce and U rban Society, 15 00-1700. Gdańsk-Danzig and $i$ ts Polish Context (Aldershot, Burlington, 2003), Ch. 1.

- Bogucka, M., "The role of Baltic Trade in European Development from the XVth to the XVIIIth Century", in: Journal of European Economic History, 9/1 (1980), pp. 5-20.

- Bogucka M., "Die Bedeutung des Ostseehandels für die Außenhandelsbilanz Polens in der ersten Hälfte des 17. Jahrhunderts", in: I. Bog (ed.), Der Außenhandel Ostmitteleuropas 1450-1650. D ie O stmitteleuropäischen $V$ olkswirtschaften $i n i$ hren $B$ eziehungen $z u$ Mitteleuropa (Cologne, 1971).

- Cieślak, E., "Aspects of of Baltic Sea-Borne Trade in the XVIIIth Century. The Trade Relations between Sweden, Poland, Prussia and Russia", in: Journal of E uropean Economic History, 12 (1983), pp. 239-270.

- Christensen, A.E., Dutch Trade in the B altic about 1600. St udies $i$ n the Sound $T$ oll Register and Dutch Shipping Records (Copenhagen, The Hague, 1941).

- Ehernsvärd, U., P. Kokkonen and J. Nurminen (eds.), Mare Balticum: The Baltic - Two Thousand Years (Helsinki, Ottawa, 1995).

- Faber, J.A., "Structural Changes in the European Economy during the Eighteenth Century as Reflected in the Baltic Trade" in: W.G. Heeres et al (eds.), From Dunkirk to Danzig. Shipping and Trade in the North Sea and the Baltic 1350-1850 (Hilversum, 1988), pp. 8394. 
- Glamann, K.,"The Changing Patterns of Trade", in: E.E. Rich and C.H. Wilson (eds.), The Cambridge Economic History of Europe, V (Cambridge, 1977), Ch. 4.

- Harder-Gersdorff, E., "Lübeck, Danzig und Riga. Ein Beitrag zur Frage der Handelskonjunktur im Ostseeraum am Ende des 17. Jahrhunderts", in: Hansische Geschichtsblätter 96 (1978), pp. 106-138.

- Heeres W.G., et al (eds.), From Dunkirk to Danzig. Shipping and Trade in the North Sea and the Baltic 1350-1850 (Hilversum, 1988).

- Holm, P., "South Scandinavian Fisheries in the Sixteenth Century. The Dutch Connection", in : J. Rooding and L. Heerma van Voss (eds.), The North Sea and Culture (1550-1800) (Hilversum, 1996), pp. 108-123.

- Hoszowski, S., "The Polish Baltic Trade in the Fifteenth-Eighteenth Centuries" in: Poland at the XIth International Congress of Historical Sciences in Stockholm (Warsaw, 1960) pp. 117-154.

- Israel, J., Dutch Primacy in World Trade (Oxford, 1989).

- Johansen, H., Shipping and Trade be tween the Baltic and Western Europe 1784-1795 (Odense, 1983).

- Kirby, D., Northern Europe in the Early Modern Period. The B altic World 1492-1772 (London, 1990).

- Kirby, D., and M.-J. Lissa Hinkkanen, The Baltic and the North Seas (London, New York, 2000).

- Lemmink, J.Ph.S., and J.S.A.M. van Koningsbrugge (eds.), Baltic Affairs. Relations between the Netherlands and North-Eastern Europe 1500-1800 (Nijmegen, 1990).

- Lindblad, J.Th., Sweden's trade with the Dutch Republic, 1738-1795 (Assen, 1982).

- Lindblad, J.Th., "Louis de Geer (1587-1652). Dutch Entrepreneurs and the Father of Swedish Industry", in: C. Lesger and L. Noordegraaf (eds.), Entrepreneurs and Entrepreneurship in Early Modern Times. Merchants and Industrials within the Orbit of the Dutch Staple Market (Hollandse Historische Reeks, 24) (The Hague, 1995) pp. 77-84.

- Mickwitz, G., Aus revaler Handelsbüchern: Zur Technik des Ostseehandels in der ersten Hälfte des 16. Jahrhunderts (Helsinki, 1938).

- Müller, L., The Merchant Houses of Stockholm c. 1640-1800. A comparative Study of Early Modern Entrepreneurial Behaviour (Uppsala, 1998).

- North, M., "A Small Baltic Port in the Early Modern Period. The Port of Elbing in the Sixteenth and Seventeenth Century", in: idem, Form the North Sea to the Baltic. Essays in Commercial, Monetary and agrarian History, 1500-1800 (Aldershot, Brookfield, 1996) Ch. 3.

- North, M., and F. Snapper, "The Baltic Trade and the Decline of the Dutch Economy in the 18th Century", in: J.Ph.S. Lemmink and J.S.A.M. van Koningsbrugge (eds.), Baltic Affairs. $R$ elations be tween $t$ he $N$ etherlands a nd $N$ orth-Eastern $E$ urope $1500-1800$ (Nijmegen, 1990), pp. 263-286.

- Palmer, A., Northern Shores. A History of the Baltic Seas and its Peoples (London, 2005).

- Pelc, O., and G. Pickhan, Zwischen Lübeck und Nowgorod. Wirtschaft, Politik und Kultur im Ostseeraum vom frühen Mittelalter bis ins 20. Jahrhundert (Lüneburg, 1996).

- Roberts, M. (ed.), Swedens's Age of Greatness, 1632-1718 (London 1973).

- Scammel, G.V., The world Encompassed. The First European Maritime Empires c. 800 1650 (London, 1981).

- Stiles, A., Sweden and the Baltic. 1523-1721 (London, 1992).

- Tielhof, M. van, The 'Mother of All Trades'. The Baltic Grain Trade in Amsterdam from the Late 16th to the Early 19th Century (Leiden, Boston, Cologne, 2002).

- Tracy, J.D. (ed.), The Political Economy of Merchant Empires (Cambridge, 1991). 
- Unger, W.S., "Trade to the Sound in the Seventeenth and Eighteenth Centuries", in: The Economic History Review, 12 (1959/1960).

- Voipio, A. (ed.), The Baltic Sea (Amsterdam, 1981).

- Vries, J. de, Economy of Europe in an Age of Crisis, 1600-1750 (Cambridge, 1976).

- Wieringa, J. (ed.), The Interactions of A msterdam and A ntwerp with the B altic R egion 1400-1800. Papers Presented at the Third International Conference of the 'Assocation Internationale d'Histoire des Mers Nordiques de l'Europe'. Utrecht 1983 (Leiden, 1983). 